Bhatter College Journal of Multidisciplinary Studies | ISSN 2249-3301, Vol. VII, Number 2, 2017

Approved by the UGC \& included in Google Scholar

Article url: www.bcjms.bhattercollege.ac.in/v7/n2/v7n2sc01.pdf

Article DOI: 10.25274/bcjms.v7n2.v7n2sc01

\title{
Teacher Motivation and Perception of Effectiveness of Curriculum
}

\author{
Namita Kumari ${ }^{1} \&$ Fr. Thomas Perumalil S.J. ${ }^{2}$ \\ ${ }^{1}$ Mother's International Teacher's Training Academy, Phulwarisharif, Patna. \\ Email: namita.educ@gmail.com \\ ${ }^{2}$ Xavier College of Education, Digha, Patna
}

\begin{abstract}
Teacher motivation is a point of concern for educationists, education planners and school managers. There are several theories dealing with teacher motivation from different viewpoints. The present paper is a short survey concerning the kind of opinion that motivated teachers have regarding the effectiveness of curriculum. The survey was conducted in a private CBSE-based school of Patna. The survey showed a medium positive correlation of 0.35 between teacher motivation and teachers' perception of effectiveness of curriculum. This implies that while it is true that motivated teachers in general have a positive opinion about their curriculum being effective, it is not so always. A small number are not very confident. This might be because they might be looking towards further possible improvements.
\end{abstract}

Keywords: Teacher Motivation, Teacher's Perception of Curriculum

\section{Introduction}

Teacher motivation has been an important point of concern for educationists, education planners and school managers ${ }^{1}$. It is so because of several reasons. Teacher motivation has a direct bearing on student motivation and student's drive to excel ${ }^{2}$. Teacher Motivation is a major driving force for educational reforms. Motivated teachers are more likely to work for educational reforms ${ }^{3}$ as well as for their own satisfaction and fulfilment ${ }^{4}$. The school systems run smoothly and efficiently if they have teachers that are motivated ${ }^{5}$. The issue of Teacher Motivation is complex. There are several theories dealing with teacher motivation from different viewpoints. Watt and Richardson have discussed three major theories relevant for understanding Teacher Motivation ${ }^{6}$. The expectancy value theory tries to address the question why a person chooses a particular career. This theory proposes that one's educational, vocational and other achievement-related choices are based on his abilities, beliefs and expectancies for success, as well as on the value attached to the task. The Achievement goal theory focuses on how teachers strive to feel successful in their daily work in the classroom which the teachers as well as students perceive as an achievement arena. The Self determination theory explores teacher's controlled versus autonomous motivations and their consequences for the teacher's instructional behavior, burnout and quality of student's motivation. Teacher motivation can be classified as intrinsic or extrinsic $^{7}$. Intrinsic motivation refers to motivation for engaging in an activity because it is enjoyable and satisfying. It depends on the subject's internal and personal factors. Extrinsic motivation is derived from the influence of external incentive distinct from the desire to engage in education for its own sake.

Curriculum refers to the academic content taught in a school. It refers to knowledge and skills the students are expected to learn. In a broad sense it includes the lessons that the teachers teach, the assignments and projects given to students, the books and other materials used in the course, the tests and other methods used for evaluation ${ }^{8}$. In the narrow sense it refers to the syllabus and $c 0=$ curricular 
activities that are followed in the schools. Teachers, in their teaching, follow the curriculum that is recommended by the affiliating body of the school, making their own improvisations where they feel necessary. The CBSE (Central Board of secondary Education, India), has recommended a set of textbooks and additional study material for all the classes right from the elementary level classes to the plus two level. Most of the CBSE-affiliated schools in India follow the textbooks developed by the NCERT or written by different authors on the NCERT pattern. The syllabus, textbooks and study materials are an important component of the curriculum. There are some other aspects of curriculum too. An important aspect is the school environment. Every school creates its own ambience in which the students and teachers spend a sizeable part of their active hours. This ambience becomes a part of the value system and working style of the teachers and students of that school ${ }^{9}$. The various co-curricular activities of the school are also a part of its curriculum. In every school the school authorities develop their own system of feedback for regulating the quality of teaching as well as implementing the teaching philosophy of that school. There is also a certain variation in the individual styles of the teachers.

Teachers develop their own perceptions regarding the curriculum and its effectiveness ${ }^{10,11}$. These viewpoints develop right from the training stage ${ }^{12}$. The individual working styles of teachers depend on their perception about teaching-learning, their own working habits and the expectations of the school ${ }^{13}$. They also depend on regional, social and other factors ${ }^{14}$.

A study of Teacher's perception of curriculum gives useful insights ${ }^{15,16}$. It is expected that the teacher's own sincerity towards work, seriousness and work motivation will have a role to play in forming such opinion. In the present paper we investigate whether these two things, ire. motivation to teach, and perception regarding effectiveness of curriculum bear any correlation, and if so, then what is its nature.

\section{Method and Validation}

In order to investigate this issue we carried out a study among teachers in a private school of Patna, affiliated to the CBSE Board. The school conducts primary as well as secondary level classes. A five point rating scale (numerical scale) was constructed for each of the two variables, Teacher motivation and for perception regarding effectiveness of curriculum to be administered to teachers. Although there are various methods for doing this study ${ }^{10,17,18,19,20}$, The study was carried out among 48 teachers whose answers were collected and analyzed. Since the items were not from any standardized test, the validity of these items and the reliability of the numerical scale was ascertained. We determined Construct validity of the rating scale through item-whole correlation method. The reliability of the numerical scale was measured using split half method. The numerical scales were administered to 48 teachers and the responses were analyzed. The observations are given below.

Rating scales were constructed for the two variables, Teacher motivation and Perception regarding effectiveness of curriculum. The statements were collected from various sources and compiled together. The validity of statements and the reliability of the numerical scale was ascertained. Item-whole correlation was determined to ascertain the validity of each statement. The numerical scales were first given to a pilot group. Each statement was set for a 5-point grading scale. The scores of individual statements were compared with the overall score and correlation coefficient between the two (part versus whole) were obtained. Only those statements which showed medium to high positive correlation with the whole were retained. The final set had altogether 85 statements related to Teacher Motivation and 56 statements related to perceived effectiveness of curriculum. The reliability of the numerical scales was measured using split half method. The statements comprising these scales were split into two equal parts. The responses for odd numbered statements were compared with the responses for even numbered statements. The two responses showed a very high correlation $(r)$ according to Spearman Brown formula: 0.95 in case of teacher motivation statements and 0.98 in case of perceived effectiveness of curriculum, showing a very high reliability. The rating scale was then administered to 48 teachers and the responses were analyzed.

\section{Findings}


The results were analyzed against the following background variables: (1) Gender of the participant, (2) Age of the participant, (3) Teaching experience,(4) Academic qualification, (5) professional qualification and (6) Marital status. Table 1 gives a summary of the calculated t scores. The number of participants was 48 . So the degree of freedom was taken as 46. For each of the background variables it was found that the difference between the means was below 0.05 level; thus showing that the effect of background variables was small.

\begin{tabular}{|l|l|l|l|l|l|l|l|l|l|l|l|}
\hline Variable & $\mathrm{X}$ & $\mathrm{N}_{\mathrm{X}}$ & Mean & $\mathrm{SD}$ & $\mathrm{Y}$ & $\mathrm{N}_{\mathrm{Y}}$ & Mean & $\mathrm{SD}$ & $\mathrm{t}$ score & $\mathrm{p}$ value & significant \\
\hline Gender & Male & 35 & 375 & 26 & Female & 13 & 381 & 21 & 0.75 & 0.46 & No \\
\hline $\begin{array}{l}\text { Teaching } \\
\text { experience }\end{array}$ & $\begin{array}{l}\text { Less than } 5 \\
\mathrm{yr}\end{array}$ & 18 & 376 & 19 & $\begin{array}{l}\text { More than } 5 \\
\mathrm{yr}\end{array}$ & 30 & 377 & 28 & 0.13 & 0.89 & No \\
\hline Age & $\begin{array}{l}\text { Less than } \\
35 \mathrm{yr}\end{array}$ & 12 & 378 & 14 & $\begin{array}{l}\text { More than } 35 \\
\mathrm{yr}\end{array}$ & 36 & 376 & 28 & 0.24 & 0.81 & No \\
\hline $\begin{array}{l}\text { Academic } \\
\text { Qualification }\end{array}$ & Bachelor & 22 & 376 & 25 & $\begin{array}{l}\text { Post } \\
\text { Graduate }\end{array}$ & 26 & 377 & 25 & 0.14 & 0.89 & No \\
\hline $\begin{array}{l}\text { Professional } \\
\text { Qualification }\end{array}$ & Untrained & 20 & 376 & 23 & Trained & 28 & 377 & 26 & 0.14 & 0.89 & No \\
\hline Marital status & Unmarried & 5 & 378 & 9.6 & Married & 43 & 376 & 26 & 0.17 & 0.87 & No \\
\hline
\end{tabular}

Table $1: t$ test results for Teacher Motivation scores for different background variables

\begin{tabular}{|l|l|l|l|l|l|l|l|l|l|l|l|}
\hline Variable & $\mathrm{X}$ & $\mathrm{N}_{\mathrm{X}}$ & Mean & SD & $\mathrm{Y}$ & $\mathrm{N}_{\mathrm{Y}}$ & Mean & SD & $\mathrm{t}$ score & $\mathrm{p}$ value & significant \\
\hline Gender & Male & 35 & 230 & 27 & Female & 13 & 218 & 21 & 1.44 & 0.16 & No \\
\hline $\begin{array}{l}\text { Teaching } \\
\text { experience }\end{array}$ & $\begin{array}{l}\text { Less than } 5 \\
\mathrm{yr}\end{array}$ & 18 & 224 & 17 & $\begin{array}{l}\text { More than } 5 \\
\mathrm{yr}\end{array}$ & 30 & 228 & 30 & 0.52 & 0.61 & No \\
\hline Age & Less than 35 & 12 & 227 & 13 & $\begin{array}{l}\text { More than 35 } \\
\mathrm{yr}\end{array}$ & 36 & 226 & 29 & 0.12 & 0.91 & No \\
\hline $\begin{array}{l}\text { Academic } \\
\text { Qualification }\end{array}$ & Bachelor & 22 & 229 & 24 & $\begin{array}{l}\text { Post } \\
\text { Graduate }\end{array}$ & 26 & 224 & 28 & 0.66 & 0.51 & No \\
\hline $\begin{array}{l}\text { Professional } \\
\text { Qualification }\end{array}$ & Untrained & 20 & 231 & 19 & Trained & 28 & 223 & 30 & 1.05 & 0.3 & No \\
\hline Marital status & Unmarried & 5 & 228 & 6 & Married & 43 & 226 & 27 & 0.16 & 0.87 & No \\
\hline
\end{tabular}

Table $2: \mathrm{t}$ test results for perception of effectiveness of curriculum-scores for different background variables

We find that the difference of means is very small for all background variables except in the case of gender. But here also, the difference is less than the required 0.05 significance level. A bigger sample size might give a more definitive answer.

We calculated the correlation between $X$ and $Y$ scores. The correlation was positive and the value of correlation coefficient $r$ was 0.348 . The positive correlation suggests that in general, the motivated teachers have a relatively positive attitude regarding the effectiveness of curriculum.

\section{Discussion}

The motivation of Teachers is a complex issue. From the day a teacher joins duty to the day of retirement, he is always learning something or other about the teaching-learning process. He goes through many different stages. According to Helen and Richardson ${ }^{6}$, comparatively little attention has been given to teacher motivations at different points along a teacher's working life. Huberman ${ }^{22}$ has suggested that teacher motivations are not stable. Day et al. have also reaffirmed this view ${ }^{23}$. There have been several 
studies involving teachers' perception regarding specific items of the curriculum. For instance, Awofala et al. ${ }^{16}$, who studied teachers' perception about newly introduced Mathematics curriculum in Nigeria schools, found that teachers, irrespective of gender or academic qualification, had high perception regarding the curriculum. Even though a majority of teachers were not acquainted with the basic principles underlying the curricular modifications, they were willing to internalize the contents. Choi ${ }^{24}$ conducted a study on motivation of Korean English teachers in which she observed that they were strongly affected by their belief in their capability to teach English. She observed that teaching style of these teachers was less affected by intrinsic components than the principal's management style and other extrinsic factors. Only a few teachers are ready to venture into the unknown. Doherty and Travers ${ }^{13}$, who carried out a study on Teacher's perception of factors influencing the curriculum, asked the teachers to assess how much freedom they felt that they should have to determine the content of what they taught in the classrooms, against how much freedom they felt they actually had in this respect. They found that there was a definite tendency to take a "middle way" between total freedom and total constraint in both cases. Teaching involves several pedagogical skills. Nicholas and Boadu, in a study on Education students in the University of Cape Coast, Ghana, ${ }^{12}$ have identified eight pedagogical skills that education students felt necessary for quality teaching. (1) team work and cooperation, (2) participation in development work, (3) continuous learning through self-evaluation and reflection, (4) Creation of learning environment, (5) School administration, (6) Classroom management, (7) Competencies in school community management, and (8) teaching method. Iliya and Ifeoma ${ }^{18}$ also concluded that discovering what matters to teachers and how best to motivate them for sustained and improved performance is a complicated challenge. Extrinsic rewards have generally not produced the desired results. They concluded that teachers are most likely to value intrinsic rewards such as self respect, responsibility and a sense of accomplishment, and participatory school improvement programs, comprehensive and meaningful staff development and supportive teacher evaluations hold great promise for improving teacher's professional motivation.

These above studies show that Teacher motivation is multidimensional. Also, correlational studies could be quite sensitive to the specific factors chosen. Our rating scale involved an assortment of factors, in which case there could be an averaging tenmdency. The correlation which we obtained between Teacher motivation and perception of effectiveness of curriculum was +0.38 which is reasonably strong for concluding that in general motivated teachers have a positive view regarding their curriculum. But this study does not rule out the possibility that there might be cases where the relation might be neutral or even negative. Also, since the present study is correlational in nature, it does not establish any causal relation between the two parameters. Some of the studies have, in fact shown that among the highly motivated teachers, there is a small number of those teachers who do not hold a very positive opinion about their curriculum. ${ }^{3,21}$ This lack of confidence in the curriculum need not always be a liability. It might also imply that they are looking one step further towards possible improvements. It is our opinion that such teachers carry valuable first hand insights and should be encouraged to give feedback towards further improvement in pedagogy.

\section{Conclusion}

We conducted this study because we felt a need to understand whether the opinion of teachers regarding their curriculum had anything to do with their motivation to teach. We found that there was a reasonably good positive correlation between these two variables. At the same time, on going through the literature concerning research work of other authors, we found that while our results have rough matching with them, yet there are some clearly opposite views such as by Judith $W$. Little ${ }^{21}$. This study also brought out what some of the other researchers have found in their contexts ${ }^{11,15}$, i.e. there is a large communication gap between those that frame the curriculum and those who implement it. This is rather unfortunate, because it alienates the teachers from their curricula which is clearly counter productive in terms of quality of Education. So one thing that the authors would strongly recommend is to have a strong co-ordination between experts and practicing teachers. If the teachers are alienated from the curriculum, then the whole generation suffers. 
5 | Teacher Motivation and Perception of Effectiveness of Curriculum

\section{Acknowledgment}

The authors are thankful to the Managing Committee and teachers of Keshav Saraswati Vidya Mandir, Marcha Marchi Patna and Keshav Vidya Mandir,Kumharar Patna for their help and support in Data Collection for this paper, and to Dr. K.N. Singh, Retd. Research Scientist, Population Research Center, Patna University for fruitful discussions concerning Data Analysis.

\section{References}

1. Saul Neves de Jesus \& Willy Lens (2005) An Integrated Model for study of Teacher Motivation. Applied Psychgology: An International Review. 54(1), 119-134.

2. Patric J. Eggleton (1992) Motivation: A Key to Effective Teaching. The Mathematics Educator, University of Geoegia. 03, 02. (http://math.coe.uga.edu/TME/Issues/v03n2/Eggleton.pdf)

3. Judith Warren Little (1994) Teacher's Professional development in a climate of Educational Reforms. Systemic Reforms: Perspective on personalising Education. Ed. Ronald J. Anson. US Dept. Of Education Ref: ED376557.

4. Geert Kelchtermans (2005) Teachers' emotions in educational reforms: Self-understanding, vulnerable commitment and micropolitical literacy. Teaching and Teacher Education 21 (2005) 995-1006. DOI:10.1016/j.tate.2005.06.009.

5. Maryam T. Abbah (2014) Employee Motivation: The Key to Effective Organizational Management in Nigeria. IOSR Journal of Business and Management 16(4), 1-8. E-ISSN: 2278- 487X.

6. Helen MG Watt and Paul W. Richardson (2015) Teacher Motivation. International Encyclopedia of the Social and Behavioral Sciences, $2^{\text {nd }}$ Ed. 24, 64-71. http://dx.doi.org/10.1016/B978-0-08-097086-8.26082-0

7. Harun Gultekin \& Erkan Acar (2014) The Intrinsic and extrinsic factors for Teacher Motivation. Revista de cercetaire si interventie sociala, 47, 291-306. E-ISSN 1584-5397.

8. Hidden Curriculum (2014 August 26) in S. Abbott (ed.) The Glossary of Educational Reform. Retrieved from http://edglossary.org/hidden-curriculum

9. Amardeep Singh (2011) Evaluating the impact of Value Education: Some Caser studies. Internatiol Journal of Educational Planning and Administration, 1(1), 1-8. http://ripublication.com/ijepa.htm

10. Kristine A. Gansle, Dora N. Gilbertson \& Amanda M. VanDerHeyden (2006) Elementary School Teacher's perceptions of Curriculum-based Measures of written expression. Practical Assessment, Research and Evaluation 11(5), 1-17. ISSN:1531-7714.

11. Ghazala Kausar, Raja Nasim Akhtar (2012) Teacher's Perception regarding the Effect of Curriculum and Examination System on Pakistani College Students' English Language performance. Journal of Education and Practice, 3(16), 219-222. ISSN: 2222-1735(paper), 2222-288X (online).

12. Oden, Sarah Nicholas \& Kankam Boadu (2013) Perception of Curriculum Innovation Needs for Pedagogical and Act Competencies among Education Students in University of Cape Coast, Ghana. International Journal of Humanities and Social Sciences 3(8) Special Issue, 245-255.

13. Jim Doherty \& Margaret Travers (1984) Teacher's Perceptions of Factors Influencing the Curriculum. Educational Studies. 10(3) 195-208. Published online Aug 2006 by Taylor \& Francis Online. (http://dx.doi.org/10.1080/0305569840100301)

14. Chidliebre R. Onyia, Obiamaka Egbo \& Nkechi Onyeneho (2016) Demographic and Cognitive Factors in Teachers' Perception of Curriculum Innovations in Enugu state, Nigeria. Mediterranean Journal of Social Sciences, 7(2), 331-342. ISSN 2039-2117 (online), 2039- 9340 (print).

15. Salem Ramdan Altaieb (2013) Teachers' Perception of the English language Curricum in Libyan Public Schools: An investigation and Assessment of implementation process of English curriculum in Libyan public high schools. Electronic Theses and Dissertations. Paper 26.

16. Adeneye Olarewaju Adaleye Awofala, Samuel Adejare Ola-Oluwa, Alfred Olufemi Fatade (2012) Teachers' Perception of the new Nine-Year Basic Education Mathematics Curriculum in Nigeria. International Journal of Mathematics Trends and Technology. 3(1), 1-6.ISSN:2231- 5373. 
6 | Bhatter College Journal of Multidisciplinary Studies, Vol. VII, No.2, 2017, Section I

17. Claude Fernet, Caroline Senecal, Frederic Guay, Herbert Marsh, Martin Dowson (2008) The Work Task Motivation scale for Teachers (WTMST). Journal of Career Asserssment. 16(2), 256-279. DOI:10.1177/1069072707305764.

18. Amos Iliya \& Loco Grace Ifeoma (2015) Assessment of Teacher Motivation approaches in Less Developed Countries. Journal of Education and Practice. 6(22), 10-17.ISSN:2222-1735 (Paper), 2222-288X (online).

19. Emily R. Lai (2011) Motivation: MA Literature Review. Downloaded from http://images.pearsonassessments.com/images/tmrs/Motivation_Review_final.pdf

20. Elif Aldemir \& Ali Arslan (2013) Development of Motivation scale for Teachers. Procedia- Social and Behavioral Sciences. 106, 860-864.DOI: 10.1016/j.sbspro.2013.12.098.

21. Judith Warren Little (1996) The Emotional Contours and Career Trajectories of (Disappointed) Reform Enthusiasts. Cambridge Jour. Education.26(3), 345-359. DOI:10.1080/0305760260304.

22. Huberman M. (1993) The lives of Teachers. Teacher's College Press, New York.

23. Day, C., Sammons, P., Stobart, G., Kington, A., Gu, Q., 2007. Teachers Matter:Connecting Lives, Work and Effectiveness. Oxford University Press, Berkshire.

24. Sunhee Choi (2014) A Measure of English Teacher Motivation: Scale Development And Preliminary Validation. Advanced Science and Technology Letters, 59, 85-88. http://doi.org/10.114257.astl.2014.59.19

Namita Kumari has obtained M.Ed. from Patna University and is presently a Faculty member in Mother's International Teacher's Training Academy Phulwarisharif, Patna. She is currently pursuing Doctoral degree from Magadh University Bodhgaya under guidance of Father Thomas Perumalil.

Fr. Thomas Perumalil is currently the Principal of Xavier College of Education Digha, Patna. 